\title{
Household Conditions and Academic Performance of Students From the Mfantsiman Municipality in the Central Region of Ghana
}

\author{
Isabella Bruce, Lucy Effeh Attom \\ Department of Social Studies Education, University of Education, Winneba, Ghana
}

\begin{abstract}
Household conditions play very critical role in children's academic performance. The purpose of the study was to examine the relationship between household conditions and academic performance of students in Mfantsiman Municipality. The theory adopted for this study was the household production theory. The study adopted quantitative approach and descriptive survey design. Stratify and random (proportional) sampling techniques were employed to select 104 respondents for the study. Questionnaire were employed for data collection and continuous assessment records of sampled students were also analyzed. The findings of the study show a significant positive relationship between household conditions, parental contribution in education and students' academic performance. It was revealed that the higher the socio-economic status of parents, the higher the performance of students. Also, the lower the socio-economic status of parent, the lower the academic performance of students. However, there were some exceptions where some students from low socio-economic background perform academically better than those from high socio-economic background due to high intelligent quotients (natural endowment). It is therefore, recommended that parents should play a leading role in their children's education by encouraging their wards to discuss issues related to their academic work with them. They should provide their wards educational needs and appropriate support in school work. Playing such active role will result in an improvement in academic performance.
\end{abstract}

Keywords: Academic Performance, Household Conditions, Teaching and Learning, Senior High Schools, Students

DOI: $10.7176 /$ RHSS/11-24-03

Publication date: December $31^{\text {st }} 2021$

\section{INTRODUCTION}

Education plays an essential role in the attainment of knowledge and skills. It is an instrument used to train the future generations to inculcate in them skills and competencies. Consequently, most family are concern with education of their young ones. Family background plays significant roles in a child's life. Family background refers to all the items or material resources, forces and conditions in the family which influence the child physically, intellectually and emotionally (Muola, 2010). Children from different family backgrounds are likely to be affected differently by such variables. Some children have good family backgrounds while family backgrounds of others are poor. The way a child is raised has a great impact not only on that child but the whole society. Growing up, a child spends most of the time at home and so the type of environment that he or she is brought up is crucial to the total development of that child.

The United Nations Report (2015) highlighted quality education as a basic right and need which is significant in the accomplishment of the fourth goal of the Sustainable Development Goals (SDGs). This is because good education, and for that matter, high academic performance guarantees the upbringing of skilled and dynamic citizens. Sustainable development is a development that meets the needs of the present without compromising the capability of future generations to meet their own needs (Bermejo, 2014). Research indicates that parental involvement is an effective strategy to ensure student's success (Barnard, 2004; Hill \& Craft, 2004; Hill \& Taylor, 2004). Parental involvement has many positive effects on students in various ways, including increased motivation, self-reliance, and self-esteem, which may lead to academic success regardless of economic background. On the other hand, research supports that inadequate parental involvement contributes to low students' achievement and engagement (Bower \& Griffin, 2011). In essence, parents, children, and other significant relatives can create rich learning environments to augment children's academic development.

Factors such as low family income, low levels of education of the parents, poor involvement of parents and other family members in students' academics and school activities may affect students' performance. Education not only provides knowledge and skills, but also inculcates values, training of instincts, fostering right attitudes and habits. In the words of Muhammed and Muhammed (2010), cultural heritage and values are conveyed from one generation to another through education. The responsibility of training a child always lies in the hand of the parents. This is congruent with the common assertion by sociologist that education can be an instrument of cultural change which is being taught from home. This is relevant in current discourse (Chakraborty, 2018).

It is not out of place to imagine that parental socio-economic background can have possible effects on the 
academic achievement of children in schools. Whatsoever affect the developmental stage of children would possibly affect their education or disposition to it. Parental status is one of such variables. "Parents of different occupational classes often have different styles of child rearing, different ways of disciplining their children and different ways of interacting with their children. These differences do not express themselves consistently as expected in the case of every family, rather they influence the average tendencies of families for different occupational classes" (Rothestein, 2004, p.1).

A person's education is closely linked to his life chances, income, and well-being (Battle \& Lewis, 2002). Therefore, it is important to have a clear understanding of what benefits or hinders one's academic achievement. Family is the initial contact where the child learns the concept of authority, good manners and respect for elders. It also determines the intellectual development of the child through activities that develop language and number competence in the child (Jekayinfa \& Oke, 2003). Academic performance of students is the pivot around which the whole education system revolves. The success or failure of any educational system is measured in terms of academic performance of students. Not only the schools, but parents also have very high expectations of students with respect to their academic performance. They believe that better academic results may lead to better career opportunities and future security. Academic performance is the outcome of education, the extent to which a student, teacher or institution has achieved their educational goals. Lee (2013) refers to academic performance as the knowledge and skills that students have mastered in a subject or a course. It is basically a measure of how well students have performed in the various assessment items set for them based on some educational criteria determined by professional educators. The academic performance of an individual is influenced by various factors such as school environment, teachers, pedagogical and content knowledge, intelligent quotient and household conditions of the student. The emphasis of household conditions other than other factors mentioned in this research is due to the fact that the academic performance of any student cannot be separated from the home environment in which the child lives; healthy home environment offers emotional security to a child (Obeta, 2014). Other reason includes to demystify the notion that the mass failure or students' success in academics must be laid down at the doorsteps of teachers and school authorities only without consideration of household conditions. Education has as one of its basic tasks to provide training for young people to become useful members of the society; this training begins at home and in the informal way.

The home environment is the immediate surroundings in which the students find themselves. It is also referred to as the physical and psychological conditions that affect children (Ogbemudia \& Aiasa, 2013). The parents or guardians of the students are responsible for providing the right household conditions that will facilitate effective learning of their wards. When a child misbehaves or fails to meet expectations at school, the child's home and family life must be considered. Several family factors can affect a child's behaviour and ability to perform in the classroom. These include economic stability, changes in family relationships, parental attitude toward education and parental involvement. Home environment strongly influence children's intellectual development during infancy and early childhood, when they are under the direct influence of parents. As children mature, schools and peers also begin to play a role in their intellectual socialization. There is much evidence supporting the hypothesis that the quality of a child's early learning in the home environment relates positively to the development of intelligence and reading skills (Meece, 2002).

Parental involvement in schooling also predicts achievement (Luckner et al., 2004). Variance in psychosocial and emotional fortification in the family background could be an indicator to high or low academic performance of students, bearing in mind the intervening effect of high and low socio-economic status and emotional stability of students which is a pre-requisite for academic achievement (Adebule, 2004). This is because psychological problems are potential sources of trouble that impedes learning. The United Nations (UN), (2010) cited in GSS (2010) recommended the definition of a house as a structurally separate and independent place of abode such that a person or group of persons can isolate themselves from the hazards of climate such as storms and the sun. The definition covers any type of shelter used as living quarters such as separate houses, semi-detached houses, flats/apartments, compound houses, huts, tents, kiosks and containers. Information collected on housing by the 2010 Population and Housing Census (PHC) in Ghana include the type of dwelling unit, main construction materials used for walls, floor and roof, household/tenant arrangement, ownership type, type of lighting, source of water supply and toilet facilities and method of solid and liquid waste disposal (GSS, 2010). The 2010 PHC also defined a household as a person or a group of persons, who live together in the same house or compound and share the same catering arrangements. In general, a household consists of a man, his wife, children and some other relatives or a house help who may be living with them. However, it is clear that members of a household are not necessarily related by blood or marriage because non relatives such as house helps may form part of a household.

Households are important units in the developmental agenda of nations all over the world. This is because it is one of the units which measure the impacts of development interventions. This is where wealth and poverty conditions of a country are often expressed. Since households have members, it is also the unit for supplying members with the needed resources for survival. Generally, household is the unit where members depend on one 
common pool of resources. Household conditions therefore mean the family background of the students which include all the human and material resources present in the home that affect the student's education and living, such as the parent's level of education, their occupation, economic status, family size, parents' involvement in children's education and socializing facilities available in the home. Thus, the home is the basic institution for providing the child's primary socialization and laying the educational foundation for the child upon which the other agents of socialization are built. The education received by a child from parents and others at home is most likely to have a highly significant and dominant effect on the behaviour of the child later in life. What the child learns at home and how his/her family motivates him/her towards education contributes to the child's success or failure. In Ghana, children can be from different cultures, and have different background experiences which contribute to the different levels of academic performances. Family socio-economic status (SES) can be classified as High, Middle and Low SES depending on variables such as parental education, parental occupation and household resources or possessions (Schulz, 2005).

In addition, research has shown that in Ghana, 87 percent of students from low socio-economic homes enter primary schools, but only 72 percent graduate, compared to 100 percent enrolment for children from high socioeconomic homes, of which 80 percent graduate (UNESCO, 2013). Moreover, 60 percent of children from low socio-economic homes enter primary school at least two years older than the official age, compared to 32 percent of children from high socio-economic homes (UNESCO, 2013). Today, more than 262 million children and youth are out of school (UNESCO, 2015). Six out of ten are not acquiring basic literacy and numeracy after several years in school. According to UNESCO (2015), 750 million adults are illiterate, fueling poverty and marginalization.

The United Nations Educational Scientific and Cultural Organisation (UNESCO, 2018) indicated the value for school enrollment for preprimary (\% gross) in Ghana was 114.55 as of 2018. In the past two decades, several social intervention programmes, including the Livelihood Empowerment Against Poverty (LEAP), Capitation Grant, School Feeding Programme, Free distribution of school uniforms, exercise books and textbooks, elimination of schools under trees, and now Free Senior High School have been implemented with the aim of ensuring universal access to education in Ghana. Other projects aimed at improving health care delivery have also been implemented. These include the establishment of Community-based Health Planning Services (CHPS), national immunization against polio and indoor residual spraying against malaria carrying mosquitoes. Again, since the last Ghana Living Standards Survey (GLSS5), the Ghanaian economy has continued to benefit from strong economic growth leading to the achievement of lower middle-income status.

However, it remains to be seen whether this growth has benefitted all sections of society. The involvement of parents in the education of the child is very crucial. Parents play very important in providing environmental, social and economic factors, which have powerful effects on pupils' academic lives. Research has consistently indicated that parental involvement is integral to high students' academic achievement (Fan \& Wiliams, 2010). The challenges of single parenthood, poverty, family crises and the ever-increasing involvement of women in various areas of community and national development make one to ask questions as to whether parents are still able to be more committed to their wards; or whether they are putting enough efforts towards developing effective learning habits among their children. The role of parents in the education of their children cannot be underestimated. Parents help to ensure that their children complete their homework, assignments and study for tests, quizzes and examinations. Parents also encourage their children to seek additional help from their teachers. Unfortunately, the reality is that many parents are not involved in their children's education as expected.

In recent times teachers have been criticized for the low performance of students in schools forgetting that education is not only a teacher or school affair. The education of the child is a collective responsibility involving the home of which the parents play a major role, the school and the wider society. Parental attitudes towards education are critical and affect the child's performance. Children learn first by mimicking behaviours they see modeled for them. Children whose parents encourage academic success are more likely to develop their own aspirations for higher education (Nyarko, 2011). In this way, parents' encouragement is a good predictor of a child's academic success. Over a period of time, it has been observed that students exposed to the same lessons by the same teachers perform differently when they are evaluated (Adesehinwa, 2013). This shows that outside the school environment, other factors can influence students' academic performance. Also, research has shown that differences in the academic performance of gifted and non-gifted children cannot be traced to school environment (Adesehinwa \& Aremu, 2010). Hence, many other uncontrolled variables can be responsible for academic performance of students. Adell (2002) consider family background as the most important and most weighty factor in determining the academic performance attained by the student.

Among family factors of greatest influence are social class variables, the educational and family environment. Emeke (1999) stressed that the environmental condition and the nature of social interaction that goes on in the family may have some positive or negative influence on the academic achievement of a child. The menace of academic failure among the young school graduates is of concern to both the government and other stakeholders. There is a consensus of opinion about the falling standards of education as a big problem that is 
hindering the posterity of the nation in terms of quality man power resources. Most students in Senior High Schools (SHS) in Ghana experience academic problems that manifest in the form of poor academic performance. Many researchers have sought to find out the reasons for the downward trend in the academic performance of students. Adesehinwa (2013) reported effects of family type and poor funding on students' academic achievement; Ogbemudia and Aiasa (2013) reported lack of good home foundation for pupils as the cause of poor performance by students. Adesehinwa and Aremu (2010) posited that factors resident in the child, family, society, government and the school may be composite causative effects for these downtrends. They however concluded that there is a need for each of these variables to be considered extensively. Hence, the focus of this study was to critically consider the effects of household conditions on academic performance of Senior High School Students in Mfantsiman Municipality in the Central Region of Ghana. This study was guided by the research question: What is the relationship between the socio-economic status of parents and academic performance of Senior High School Students in the Mfantsiman Municipality? The study was also aimed at testing this hypothesis: $\mathrm{H}_{0}$ : Students from high socio-economic status families do not perform better academically than those from medium and low socio-economic status families. The study was conducted in three Senior High Schools out of the four (4) public Senior High Schools in the Mfantsiman Municipality. In addition, the study was delimited to parents' socio-economic status and how these conditions influence students' academic performance in Senior High Schools in Mfantsiman Municipality.

\section{THEORETICAL PERSPECTIVE AND LITERATURE REVIEW}

Many theories have been propounded to explain the educational attainment of children. Some of them concentrate on the immediate environment of children whilst others consider both the immediate and external environment. This study was guided by Gary Becker's (1993) Household Production Theory. The household production theory is an outgrowth of two theories; namely the human capital theory and the theory of allocation of time. These two theories view education as an investment rather than consumption. Gary Becker's household production theory directly links household resources and investments to the educational attainment of children (Becker, 1993). In the household production function approach, it is assumed that a combined household utility function is maximized and resource allocation decisions are made through the "benevolent dictatorship" of the household head (Becker, 1993). The decision to take a child to school or give him/her a higher education then becomes dependent on the household head, all things being equal. The characteristics of the household head such as sex, educational level, marital status, employment and income status will therefore play a huge role in determining the level of education of the child.

However, there has been much evidence to suggest that this assumption does not always hold and that resource allocation decisions are made by other members of the household as well as the household head (Haddad et al., 1994; Kabeer, 1991). Bargaining approaches to household decision-making assume that resource allocation decisions are made through a process of bargaining between individual members of the household. The stronger the bargaining power of a family member, the more influence he/she will have on resource allocation decisions (Sen, 1990). Bargaining power will be dependent on individual's characteristics and therefore the attributes of other household members, as well as the household heads will be relevant when looking at schooling decisions of the child. For instance, an educated mother is likely to have more bargaining power within the household and her preferences for educated children will play a larger role in the decision to send her children to school (Al-Samarrai \& Peasgood, 1998).

Household economists consider the family as not only a consuming unit but also as a producing unit. This theory states that a combination of time and resource inputs produce different types of commodities (Becker, 1993). In order to produce what Becker calls "quality children," parents must spend time at home and devote real resources to foster an environment that promotes and provides formal education. Many scholars have applied this theory in different ways. For instance, Ermisch and Francesoni (2001) used the household production theory to examine the correlation between childhood parental employment, parental education levels, and education of children. Their findings show that time and money is two major factors that affect children's educational attainment. Children whose mothers work more during their children's early stages of life have less educational attainment compared to children whose mothers spend more time at home with them (Ermisch \& Francesoni, 2001).

A person's education is closely linked with his or her life chances, income and general well-being. Therefore, the success of students in any academic task has become a major concern to educators, parents, researchers and society in general. Literature indicates that there is lack of specific or universal definition of academic performance (Hijazi, \& Naqvi, 2006). This is because academic performance is a multidimensional construct composed of the skills, attitudes, and behaviours of a learner that contribute to academic success in the classroom (Hijazi, \& Naqvi, 2006). To other researchers, academic performance is determined by examination grades at the end of a particular term, semester or programme (Tinto, 1993). Higher scores indicate better academic performance. It is a satisfactory and superior level of performance of students as they progress through 
and complete their school experience. The implication of this definition is underscored by studies which repeatedly demonstrate that the vast majority of students who withdraw from school do so for no reason other than poor academic performance. Academic performance can be measured at multiple levels and serves multiple purposes. For instance, it has been indicated that classroom teachers often conduct formative and summative tests to evaluate student mastery of course content and provide grades for them and their parents (Elliot, 2007). Graduation tests in particular are used to determine whether a student has mastered the minimum content and competencies required to receive a high level of education. Each of these kinds of assessments engenders significant questions related to test design, types of decisions supported by the results as well as alternative assessment (Elliot, 2007; Johnson, 2003).

A number of studies have been conducted to explore the factors that affect academic performance of students in a number of educational institutions. Majority of these studies have focused on parents (family causal factors), teachers (academic causal factors), and students (personal causal factors) (Diaz, 2003; Georgiou, 2007; Fan \&Williams, 2010). Even though combinations of these factors influence academic performance of students, they vary from one academic environment to another, from one set of students to the next, and from one cultural setting to another (Diaz, 2003). Individual characteristics such as previous school achievements, academic selfefficacy or study motivation have been identified to correlate with academic performance (Anderson, Benjamin, \& Fuss, 1994). Also, socio-economic background with specific reference to parents' education has been shown to have a positive influence on the academic performance of students (Jeynes, 2003; McMillan \& Western, 2000; Nyarko, 2011).

There is always the issue of socio-economic background and academic performance. The socio-economic status of a family is capable of affecting the behaviour of the children and determines their aspiration. Families with high socio-economic status often have more success in preparing their children for school because they typically have access to wide range of options that provide their young children with high quality child-care, books and encourage children in various learning activities at home. They also have easy access to information regarding their children's health, as well as social, emotional and cognitive development (Ojo \& Yilma, 2010). Ojo and Yilma (2010), further noted that in all socio-economic groups, parents face major challenges when it comes to providing optimal care and education for their children and these challenges are more pronounced in poor families. This, according to them, is because sometimes, when the basic necessities are lacking, parents place top priority on housing, food, clothing and health care, regarding education materials and books as luxuries. They added that poor families may also have inadequate or limited access to community resources that promote and support children's development and school readiness. They further asserted that these disadvantages can negatively affect families' decisions regarding their children's development and learning. The situation according to Ojo and Yilma (2010) may also expose the infants in poor families to a greater risk of entering kindergarten schools unprepared unlike their peers from rich families.

Again, the health status of children which could also be traceable to parental socio-economic background can be another factor that can affect the academic performance of the students. Adewale (2002) reported that in a rural community where nutritional status is relatively low and health problems are prevalent, children's academic performance is greatly hindered. This assertion is again hinged on the nature of parental socio-economic background. Moreover, Eze (2002) had opined that when a child gets proper nutrition, health care and motivation during pre-school years, the ability to interact and take optimal advantage of the full complement of resources offered by any formal learning environment is enhanced. Goodlad (1984) has found a relationship among the courses opted by different children belonging to different socio-economic status families. The students from higher income families tend towards the costly and more beneficial courses while the students of poor families go towards the cheaper study programmes. Ramey and Ramey (1994) are of the view that great challenges are faced by parents at the time when they start to send their children to the schools.

Hill et al. (2004) have suggested that the socio-economic status of parents not only influences the development of children at home but it also develops a competition among the students belonging to persons of different social and economic strata. The children of parents belonging to low socio-economic status feel depressed as against students from higher socio-economic status. Laosa (2005) states that the differences among the students exist due to the family backgrounds such as nutrition and health status, environment at home, income of parents, their educational level and experiences as well as means of recreation in the family are the main factors that affect the educational and social achievement of students. In the same vein, other researchers had posited that parental SES could affect school children as to bring about flexibility to adjustment in different school schedules (Guerin et al., 2001). The same view is shared by Machebe (2012) in her research that concluded that parental socio-economic status could influence academic performance of their children at school. It can therefore be deduced that parental socio-economic status might be a factor that can influence student academic performance. In their findings, Oni (2007) and Omoegun (2007) have concluded that a significant difference exists between the rate of deviant behaviour and the students belonging to different socio-economic statuses. 
The findings of Oni (2007) and Omoegun (2007) revealed that children from low-income families are more likely to exhibit deviant behaviour than children from high-income families. This is because parents of lowincome families lack control over their children as a result of their inability to provide the basic needs of the children such as food, clothes, shelter and education. Francis (2007) opines that the lower income families may be aware of the importance of education in the society, but at the same time, they are also aware of their limited resources to measure up with such educational demands. Francis (2007), further indicated that a family that can scarcely provide for the basic needs of the family which include food, shelters and clothing will hardly motivate the academic excellence of their children. They will rather pressurize their children to seek for job opportunities with the little education they acquired so far to support the family. The implication of the agreement is that poor families are likely to give their children poor academic background because of lack of financial support.

Filmer and Pritchett (2001) developed an asset index which included household possessions and household structural characteristics and classified them into different wealth groups (poor, middle, rich) based on the asset index values. The advantage of an asset index is that it can be used to evaluate the distribution of educational outcomes across different socio-economic status groups within countries (Filmer \& Scott, 2008). Economic resources such as income and assets which are indicators of parent and household socio-economic status influence youth's academic performance. Household income and wealth have been shown to be associated with improvements in children's education in developing countries including Sub-Saharan Africa (Glick \& Sahn, 2009; Lincove, 2009; Zhao \& Glewwe, 2010). According to Grim et al. (2020), decline in income has been shown to negatively affect school enrolment of children in developing countries. Research has also shown that changes in youth's levels of educational aspiration or expectation are influenced by household socio-economic status (Hossler, Schmit \& Vesper, 1999; Reynolds \& Pemberton, 2001). One way that asset ownership, particularly liquid assets, influence youth academic achievement is through a family's ability to purchase school materials (for example, text books and other needed supplies) that can facilitate learning both in and outside of the classrooms. For instance, research has shown positive association between household computer ownership and children's academic performance (Schmitt \& Wadsworth, 2006) and school enrolment (Fairlie, 2005).

According to Bjorkman (2005), a negative income shock has rippling effects on the female students' performance; only brighter girls reach grade seven because of few resources within the household and or alternatively, have to spend more time on domestic work as compared to boys which cause girls to perform worse on test as compared to boys. A study conducted by Sentamu (2003) in Mukono District on the influence of family income on students' performance at school revealed that family income was the determinant of the kind of a school a child attend. Ojeka (2011) asserts that the present economic hardship facing parents makes it difficult for them to cater for themselves and their families. The situation has led to a lot of children engaging in income generating activities with the aim of supplementing their parents' financial resources much to the neglect of their own education leading to poor academic performance. Attaining quality education in this modern era requires financial commitment and educational material inputs from parents to supplement what educational providers have been able to provide for learners.

Similarly, Suleman et al. (2012) found that those children whose socio-economic status was strong showed better academic performance whilst those with poor socio-economic status showed poor and unsatisfactory academic performance. Heyneman (2005) stated that for many years, researches have revealed that students whose parental socio-economic status is low do not show effective performance in schools. The academic achievement of students is negatively correlated with the low parental socio-economic status level as it prevents the individual in gaining access to sources and resources of learning (Duke, 2000; Eamon, 2005). Farooq et al. (2011) concluded that the higher level of socio-economic status is the best indicator which plays a fundamental role in promoting quality of students' achievement.

Unfortunately, most children born to parents with low-income do not have access to learning equipment. Most families in Ghana are poor and cannot adequately afford 3-square meals not to talk of meeting the educational needs of their children. This indeed has serious implications on the learning and performance of less privileged children in school. Children from such families are forced to miss classes, unable to do their assignments and most seriously are driven from school due to non-payment of school levies. All these have significant effects on the development of the child. It is also believed that low parental income negatively affects academic achievements since it prevents access to vital resources and creates additional stress at home (Jeynes, 2002; Eamon, 2005). The economic hardship that are caused by low socio-economic background leads to disruption in parenting, increase family conflicts, and increased likelihood of depression in parents' households (Eamon, 2005). Learners' background relating to availability of educational resources at home is very crucial. Learners who have access to such resources would be more informed about the latest developments around them, thus, assisting them to improve their performance at school while those with little or no resources will have to rely only on what the school is able to provide, even if they are not sufficient and yet write the same examination papers. On that note, these learners' non-exposure to educational resources at home because of their poor backgrounds may affect their performance compared to those who have access to such resources. 
Despite exposure to some programmes that should not be viewed by children on the television, there is a lot of educational information that can be accessed on it. Computers that are connected to the internet can assist learners to access information for school assignments and projects. Studies have proven that socio-economic status influences students' achievements (Jeynes, 2002; Eamon, 2005; Hochschild, 2003). Students whose parents are within the low socio-economic status group perform poorly in school work and are more likely to drop out of school (Eamon, 2005; Hochschild 2003). Many research studies have shown that socio-economic status is a factor responsible for the academic attainment of students. Morakinyo (2003) found that there is a relationship between socio-economic status and academic achievement of students.

In the United States (US), the gaps in achievement among poor and advantaged students are substantial (Rowan et al., 2004). Through multiple studies, the U.S. Department of Education (2001) has indicated results that demonstrated that poverty adversely affected students' achievement. Students from low-income families consistently, regardless of ethnicity or race, scored well below average (Bergeson, 2006). For example, in one study, $43.5 \%$ of low-income students did not successfully meet any of the required subject area assessments while only $13.2 \%$ of low-income students met all of the required subject area assessments (Bergeson, 2006).

The pressure on children from poor background in particular, to withdraw from school increases as they get older, particularly as the opportunity cost of their time increases (Colclough et al., 2000). In African traditional societies including Ghana, several studies indicated that the children's schooling has been found to have links with socio-economic factors. According to Barrera-Osorio et al. (2008) the most important of these factors include direct and opportunity cost of schooling, limited employment opportunities, parental and family investment behaviour, rural and urban residence and the level of parental education, which all affect the income level of the household. It has been found that the major reasons parents offer for not educating their children or for removing them from school in African societies are the fees for registration, examination, Parent Teacher Association (PTA) fees, the cost of books and uniforms, the provision of other daily monetary demands and the cost of transportation to and from the school on daily basis (Yusuf, 2013). Even though the capitation grant and free senior high school policies in Ghana ensure that the government pay some of these expenses, parents are expected to provide educational needs, food, transportation cost for their children. It is clear from existing research that children from poorer backgrounds have worse educational attainment than their better-off peers. Low-income families contain adults with characteristics that are inimical to the social, behavioural and moral development of children. In the view of Blande and Gregg (2004), there are certain characteristics associated with low-income families which significantly have negative consequences on their child's education. One of such characteristics is low parental education. The extent of financial constraints also significantly affects the harmony in the home leading to series and increases in conflicts and marriage/family break ups. All these affect the parents' ability to effectively cater for their children to bring the best out of them.

An investigation conducted by Agus and Makhbul (2002) indicated that students from families of higher income levels perform better in their academic performance as compared to those who come from families of lower income brackets. Machebe (2012) has made the conclusion that the socio-economic status of parents influences the academic performance of students to a certain degree in the schools. Likewise, Escarce (2003) maintains that most underachievers come from the lower-socio-economic levels of the home-environment and that the psychosocial encouragement here contributes very little towards improving the intellect. Contrary, Tahir and Naqvi (2006) found that there is negative relationship between student performance and student family income. Similarly, Hill et al. (2004) argued that socio-economic status of parents does not only affect the academic performance, but also makes it possible for children from low background to compete with their counterparts from high socio-economic background under the same academic environment.

Moreover, Smith, Fagan and Ulvund (2002) had stated that noteworthy predictor of intellectual performance at age of 8 years involved parental socio-economic status (SES). In the same vein, other researchers had posited that parental SES could affect school children as to bring about flexibility to adjustment in different school schedules (Guerin et al., 2001). In a previous study in Nigeria, Oni (2007) and Omoegun (2007) had averred that there is significant difference between the rates of deviant behaviour among students from high and low socio-economic statuses.

\section{METHODOLOGY}

The study adopted the quantitative research approach with a descriptive survey design. Descriptive survey design is a type of design that describes situations or characteristics of population or phenomenon being studied. This design is suitable because the study sought to identify and describe household conditions and their relationship with academic performance of students from three selected Senior High School. Robson (2002) asserts that descriptive research design studies have advantages in that they may be adopted to collect information that can be generalized from all population and that they provide relatively simple and straight forward approach to the study of values, attitudes, beliefs and motives. In addition, descriptive survey design was preferred because it gave accurate description of the association of household conditions on students' academic performance. On the 
other hand, the results from descriptive research cannot be used to discover a definitive answer (Kabir, 2018).

The area under study was Mfantsiman Municipality located in the Central Region of Ghana. The Municipality is one of the 216 Metropolises, Municipalities and Districts in Ghana. Mfantsiman Municipality is situated 110 kilometers west of Accra - the capital of Ghana. It has a population of 10,000 according to the 2000 census. The capital town of the Municipality is Saltpond. The occupation of the people is mainly fishing, farming and salts production. Educationally, according to Education Directorate, there are seven (7) Senior High Schools in this Municipality namely, Mankessim Secondary Technical SHS, Mfantsiman Girls SHS, Methodist High School, Kwegyir Aggrey Technical SHS, Biriwa Vocational Technical SHS, St. Andrews SHS (private) and Obama SHS (private) with a total of twelve thousand, four hundred and twenty $(12,420)$ students (GESMfantsiman Municipal, 2017) out of which the following three (3) schools were selected to take part in the study. The three (3) schools were Mfantsiman Girls Senior High School, Methodist High School Saltpond and Mankessim Senior High Technical School. These three schools were selected because they were public schools and are the three most populous schools in the Municipality.

In this study, students of three (3) selected Senior High Schools in the Mfantsiman Municipality constituted the population. They include Mfantsiman Girls SHS (3000), Mankessim Senior High Technical School (2000) and Methodist High SHS (1500). The total population of students of these three selected schools was six thousand five hundred (6500) (GES-Mfantsiman Municipal, 2017). The target population was made up of the form three (3) students. The sample was made up of one hundred and four (104) students comprising forty-two (42) males and sixty-two (62) females.

Sample and sampling procedure was conducted scientifically. A sample size is basically the subset of actual number of individuals of the population. It has been confirmed by some scholars in Social Science that for a sample to be representative in a study it must be a good proportion of the population (Welman, Kruger \& Mitchell, 2005; Zikmund, 1994). In all, 104 students constituted the sample.

Formular: $n=\left[z^{2} \times p \times(1-p) / e^{2]} /\left[1+\left(z^{2} p \times(1-p) /\left(e^{2} \times N\right)\right]\right.\right.$

where $\mathrm{N}=$ Population Size $(6500)$

$\mathrm{p}=$ Population proportion $(93 \%)$

$\mathrm{e}=$ Margin of error (4.1)

$\mathrm{z}=1.645$ for confidence level of $90 \%$

$\mathrm{n}=\left[1.645^{2} \times 0.93 \times(1-0.93) / 0.04095^{2}\right] /\left[1+\left(1.645^{2} \times 0.93(1-0.93) /\left(0.04095^{2} \times 6500\right)\right]\right.$

$\mathrm{n}=104.796 / 1.0161=103.133$

$\mathrm{n}=104$

Therefore, the sample size (with finite population correction) is equal to 104. The stratified and random sampling procedures (proportional) were used to select 104 students from the three selected Senior High Schools to provide better coverage and representation of the population. Third year (final year) students only were involved in the study because of their availability and the absence of first and second years in schools due to COVID-19 pandemic. Out of the total of one hundred and four (104) students sampled for the study, Mfantsiman Girls SHS students constituted 48 (46\%), Methodist high school students were 24 (23\%) whilst Mankesim Senior High Technical School students constituted 32 (31\%). 


\section{MFANTSEMAN MUNICIPALITY EDUCATION MAP}

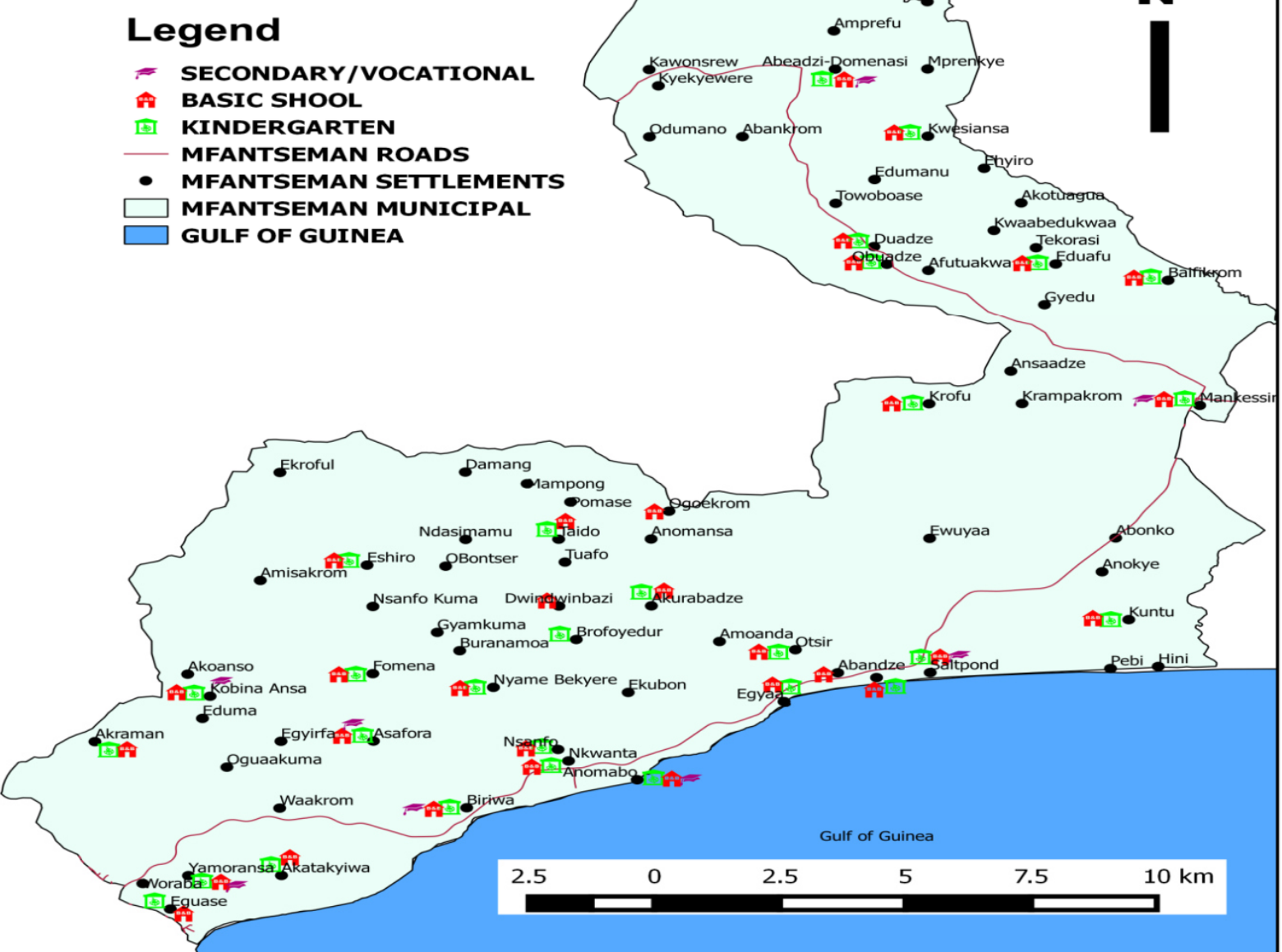

Figure 1: Map of the study area

Source: Field Survey, 2020

The main instrument used for data collection in this study was questionnaire. Deng (2010) says that a questionnaire is a form prepared and distributed to secure responses to certain questions. It is a systematic compilation of questions that are submitted to a sampling population from which information is desired. As to why the questionnaire was used, it is advantageous whenever the sample size is large enough for reasons of time or funds to consider every subject in the study (Osuala, 2005).

Questionnaire was used to elicit relevant information about the demographic data of the students (age, gender), parental financial status, parental educational background and qualification as well as the occupation of respondents' parents.

Continuous assessment records were also collected in order to obtain official assessment records of students to be analysed along with data from the questionnaire. End-of-semester examination scores for the first semester of the 2019/2020 academic year were obtained from the teachers to also confirmed the examination scores that students stated in the questionnaire. According to Yin (1994) as stated in Moshi (2007) documents are used to support and supplement evidence from other sources. The gathering of data from continuous assessment records during the data collection phase of the study helped in the research validity through triangulations, as the documentary evidence collaborated and enhanced the evidence that the researchers collected from the questionnaire. It also helped to verify the authenticity of the responses provided by students on their academic performance. 
It is essentially concerned with establishing whether the questionnaire content is measuring what it purports to measure. For the purpose of this study, the research instrument was subjected to a validity and reliability test. The research instruments were used to collect data from two (2) schools outside the study area. The schools have similar characteristics like the sample schools and they were located in Cape Coast Metropolis. This was based on the assertion by Mugenda and Mugenda (2003), that a pilot study with a sample of a tenth of the total sample with homogenous characteristics is appropriate for the pilot study. Pilot testing is an important step in research process because it reveals vague questions and unclear instructions in the instruments. It also captures important comments and suggestions from the respondents that enable the researcher to improve on the efficiency of research instrument. The researcher pre-tested the research instruments for clarification and ascertained their ability to capture all the data required to get feedback which led to improvement of the instruments.

In order to establish the reliability of the instruments, test, re-test method was used to estimate the degree to which the same results can be obtained with a repeated measure of accuracy of the same concept in order to determine the reliability of the instruments. The instruments were administered within an interval of two weeks. This enabled the researcher to modify some of the items to capture the desired data. The results obtained were correlated using the Pearson's Product Moment Correlation Coefficient of 0.84. The more the correlation coefficient was closer to 1.00 the more reliable the instrument was.

Data gathered from the field were displayed in tables, frequencies and percentages to help show the distribution of respondents. According to Kothari (2004), the most commonly used method in reporting descriptive survey research is by developing frequency distribution tables, calculating percentages and tabulating them appropriately. Correlation and cross tabulation were also used to establish the relationship among variables. Again, summary of means, standard deviation and independent t-test were used to indicate difference in academic performance and household conditions.

Ethically, there was preservation of confidentiality and the privacy of the people involved in the study. Respondents were assured of anonymity and confidentiality throughout the study. Finally, participants were informed that they can withdraw from the study without any consequences.

\section{RESULTS AND DISCUSSION}

The demographic variables that were examined in the study include class, gender, age of the students, the educational level and occupational status of the parents. The data is presented first followed by the results on the research question and hypothesis.

\subsection{Descriptive Statistics of Respondents}

The following data presents statistics on respondents that were involved in the survey. Data were gathered from one hundred and four (104) respondents that were involved in the survey. Table 1 focused on the schools of student respondents involved in the study, their frequencies, percentages as well as cumulative percentages.

Table 1: Schools of respondents

\begin{tabular}{lcc}
\hline Schools & Frequency & Percent \\
\hline Mfantsiman Girls SHS & 48 & 46 \\
Mankessim Senior High & 32 & 31 \\
Methodist High Saltpond & 24 & 23 \\
\hline Total & $\mathbf{1 0 4}$ & $\mathbf{1 0 0 . 0}$ \\
\hline
\end{tabular}

Source: Field Survey, 2020

From Table 1, out of the 104 students who were involved in the study, 48(46\%) were in Mfantsiman Girls SHS. This huge percentage was as a result of the category of students who were form three students at the time of the survey. Thirty-two (31\%) were from Mankessim SHTS whilst 24 (23\%) came from Methodist High SHS, Saltpond.

Table 2 highlighted the gender of students' respondents in frequencies and percentages

Table 2: Gender of Respondents

\begin{tabular}{lll}
\hline Gender & Frequency & Percent \\
\hline Female & 62 & 60 \\
Male & 42 & 40 \\
\hline Total & $\mathbf{1 0 4}$ & $\mathbf{1 0 0 . 0}$ \\
\hline
\end{tabular}

Source: Field Survey, 2020

With regard to Table 2, 62(60\%) were females whereas $42(40 \%)$ were males. This is as a result of the number of respondents chosen from the single sex school which is the most populous school within the Municipality. 
Table 3: Age of Respondents

\begin{tabular}{llc}
\hline Age & Frequency & Percent \\
\hline $13-15$ years & 4 & 4 \\
$16-18$ years & 82 & 79 \\
$19-21$ years & 18 & 17 \\
\hline Total & $\mathbf{1 0 4}$ & $\mathbf{1 0 0 . 0}$ \\
\hline Source: Field Survey, 2020 & &
\end{tabular}

The respondents were mostly teenagers, with $82(79 \%)$ of them being within the ages of 16 to 18 years. Whereas $18(17 \%)$ were within ages of 19 to 21 years. The remaining 4(4\%) were between the age range of 13 to 15 years. This is a clear indication that these are young students who would easily be influenced positively or negatively by a parent or guardian's involvement in their education. Table 4 focused on the categories of people the respondents stay with.

Table 4: Respondents views on who they stay with

\begin{tabular}{cll}
\hline Staying with & Frequency & Percent \\
\hline Parents & 72 & 69 \\
Father only & 4 & 4 \\
Mother only & 16 & 15 \\
Grandparents & 5 & 5 \\
Brothers & 1 & 1 \\
Sisters & 2 & 2 \\
Aunty & 1 & 1 \\
Uncle & 2 & 2 \\
Guardian & 1 & 1 \\
\hline Total & $\mathbf{1 0 4}$ & $\mathbf{1 0 0 . 0}$ \\
\hline
\end{tabular}

Source: Field Survey, 2020

In connection with categories of people respondents stay with, $72(69 \%)$ respondents lived with parents, 4 (4\%) respondents lived with father only, $16(15 \%)$ respondents lived with their mother only, $5(5 \%)$ respondents lived with their grandparents only, $1(1 \%)$ respondent lived with the brother, $2(2 \%)$ respondents lived with their sisters, $1(1 \%)$ respondent lived with the aunty, $2(2 \%)$ respondents lived with their uncles and $1(1 \%)$ respondent lived with the guardian.

Again, the Table revealed that $92(88 \%)$ of the respondents lived with their biological parents whilst $12(12 \%)$ lived with people other than their biological parents.

Table 5 represents the educational background of parents of the respondents

Table 5: Students' views on their parents' level of Education

\begin{tabular}{|c|c|c|}
\hline Variable & Frequency & Percent \\
\hline \multicolumn{3}{|l|}{$\begin{array}{l}\text { Father's highest level of education } \\
\text { Tertiary }\end{array}$} \\
\hline Post-graduate & 9 & 9 \\
\hline First degree & 15 & 14 \\
\hline Diploma & 14 & 13 \\
\hline \multicolumn{3}{|l|}{ Pre-tertiary } \\
\hline Secondary & 40 & 39 \\
\hline Middle School / JSS / JHS & 18 & 17 \\
\hline Primary & 5 & 5 \\
\hline No formal education & 3 & 3 \\
\hline Total & 104 & 100 \\
\hline \multicolumn{3}{|l|}{$\begin{array}{l}\text { Mother's highest level of education } \\
\text { Tertiary }\end{array}$} \\
\hline Post-graduate & 2 & 2 \\
\hline First degree & 7 & 6.7 \\
\hline Diploma & 12 & 11.5 \\
\hline \multicolumn{3}{|l|}{ Pre-tertiary } \\
\hline Secondary & 34 & 32.7 \\
\hline Middle School / JSS / JHS & 34 & 32.7 \\
\hline Primary & 8 & 7.7 \\
\hline No formal education & 7 & 6.7 \\
\hline Total & 104 & 100 \\
\hline
\end{tabular}


In relation to Table 5, the education level of the fathers, 38(36\%) had tertiary education, $63(61 \%)$ also had pre-tertiary education and $3(3 \%)$ had no formal education. The education level of the mothers, $21(20.2 \%)$ had tertiary education, 76(73.1\%) also had pre-tertiary education and 7(6.7\%) had no formal education. A closer look at the figures for the fathers and mothers reveal that the fathers have higher education than the mothers and also a large portion of the mothers have education up to secondary school and below. This scenario points to the skewness of educational attainment between males and females. It seems males aspire to achieve more and higher educational laurels than their female counterparts.

Data was gathered on residential status of the students and Table 6 present the data.

Table 6: Residential Status of Respondents

\begin{tabular}{llc}
\hline Type of house & Frequency & Percent \\
\hline Flat apartment & 19 & 18.3 \\
Bungalow & 8 & 7.7 \\
Detached house & 21 & 20.2 \\
Semi-detached house & 7 & 6.7 \\
Compound house & 35 & 33.7 \\
Single room & 7 & 6.7 \\
Others (Specify) & 7 & 6.7 \\
\hline Total & $\mathbf{1 0 4}$ & $\mathbf{1 0 0 . 0}$ \\
\hline
\end{tabular}

Source: Field Survey, 2020

With regards to their residential status in Table $6,19(18.3 \%)$ of respondents lived in flat apartment, $8(7.7 \%)$ lived in bungalow, 21(20.2\%) also lived in detached house, $7(6.7 \%)$ lived in the semi-detached house, similarly another $35(33.7 \%)$ of them stayed in compound house, whereas $7(6.7 \%)$ of them stayed in single room and the rest were living in other housing types.

The occupational status of fathers is represented in Table 7.

Table 7: Students views on the occupational status of fathers

Occupation
Formal (skilled)
Public sector workers
Private sector workers
Informal (unskilled)
Trading
Self-employed
Farming
Business
Unemployed
Total

\begin{tabular}{ll} 
Frequency & Percent \\
33 & 31.7 \\
10 & 9.6 \\
& \\
14 & 13.5 \\
27 & 26 \\
10 & 9.6 \\
6 & 5.8 \\
4 & 3.8 \\
\hline $\mathbf{1 0 4}$ & $\mathbf{1 0 0}$
\end{tabular}

Source: Field Survey, 2020

The occupational status of the fathers shows that 43(41.3\%) were formal sector workers (skilled), 57(54.9\%) were informal sector workers, whilst 4(3.8\%) were unemployed.

The occupational status of mothers is represented in Table 8.

Table 8: Students views on the occupational status of mothers

\begin{tabular}{lcc}
$\begin{array}{l}\text { Occupation } \\
\text { Formal (skilled) }\end{array}$ & Frequency & Percent \\
Public sector workers & 10 & 9.6 \\
Private sector workers & 8 & 7.7 \\
Informal (unskilled) & & \\
Trading & 37 & 35.6 \\
Self-employed & 29 & 27.9 \\
Farming & 10 & 9.6 \\
Business & 4 & 3.8 \\
Unemployed & 6 & 5.8 \\
\hline Total & $\mathbf{1 0 4}$ & $\mathbf{1 0 0}$
\end{tabular}

Source: Field Survey, 2020

The occupational status of the mothers shows that $18(17.3 \%)$ were formal sector workers (skilled), $80(76.9 \%)$ were informal sector workers, whilst 6(5.8\%) were unemployed. 
Table 9: Student monthly allowance

\begin{tabular}{llll}
\hline $\begin{array}{l}\text { Is the money you receive monthly for your upkeep } \\
\text { enough? }\end{array}$ & Frequency & Percent \\
\hline No & 40 & 38.5 \\
Yes & 64 & 61.5 \\
\hline Total & $\mathbf{1 0 4}$ & $\mathbf{1 0 0 . 0}$ \\
\hline Source: Field Survey, 2020 & &
\end{tabular}

Table 10: Supporting family income

\begin{tabular}{lll}
\hline Do you work to support family income? & Frequency & Percent \\
\hline No & 60 & 57.7 \\
Yes & 44 & 42.3 \\
\hline Total & $\mathbf{1 0 4}$ & $\mathbf{1 0 0 . 0}$ \\
\hline
\end{tabular}

Source: Field Survey, 2020

\subsection{Socio-Economic Status of Parent and Academic Performance}

This section was guided by this research question: What is the relationship between the socio-economic status of parents and academic performance of Senior High School Students in the Mfantsiman Municipality?

This research question sought to find out whether there is relationship between the socio-economic status of parents and students' academic performance. From the study, socio-economic status was measured using education of parents, occupation of parents, residential status/house type, and money received monthly from parents and the availability of some items at home. This was to establish the socio-economic background of the students. To achieve these, different questions were designed to reveal the socio-economic background of the students. In all, the higher the score the more likely it was that the person is from high socio-economic family and the lower the score the more likely the person is from a low socio-economic status family. The minimum score was 0 and the maximum was 8 . This was therefore categorized into Low (0-3), medium (4-5) and high (6$8)$.

This was complemented with an 8-item on a 4-point likert scale ranging from strongly disagree, disagree, agree to strongly agree. The items on the scale include: "We have enough money for everything that we need", "My parents are often worried whether they can pay their bills or not", "We often run out of money", "When I need materials for school, we sometimes don't have enough money to buy them", "I cannot do certain activities with my friends due to lack of money ie. Extra-classes, buying of stationaries and others", "I often do not have money for my educational needs because my family has to restrict its expenses". The Likert scale was rated as 1= Strongly Disagree, 2= Disagree, 3=Agree, and 4= Strongly Agree. The overall mean for the responses for the entire items was 20.74 and the standard deviation was 6.81 . With the minimum being 9 , the maximum being 36 and the mean 20.7. This was used to classify them into Low and High Socio-economic Status. Those ranging from 9 to 21 are considered to be respondents from low socio-economic background and those ranging from 22 to 36 are classified as respondents from high socio-economic background (Régner, Huguet \& Monteil, 2007). These classifications were adapted from Régner, Huguet and Monteil (2007). The result is presented in Table $11 \mathrm{a}$.

Table 11a: Socio-economic status

\begin{tabular}{ll}
\hline Mean & $\mathbf{2 0 . 7 4 0 3 8}$ \\
\hline Standard Deviation & 6.810892 \\
Minimum & 9 \\
Maximum & 36 \\
Low SES & 58 \\
High SES & 46 \\
\hline
\end{tabular}

Source: Field Survey, 2020

Alternatively, the mean for the responses was 2.3 and the minimum rating was 1 and the maximum rating being 4. In all, the higher the score the more likely it was that the person is from family with high socioeconomic status and the lower the score the more likely the person is from a low socio-economic status family. This was used to classify them into Low and High Socio-economic background. Those ranging from 1 to 2 are considered to be respondents from low socio-economic background whilst those ranging from 3 to 4 are considered as respondents from high socio-economic background. The result is presented in the Table 11b; 
Table 11b: Socio-economic status

\begin{tabular}{ll}
\hline Mean & $\mathbf{2 . 3 0 4 4 8 7 1 7 9}$ \\
\hline Median & 2 \\
Mode & 1 \\
Low SES & 58 \\
High SES & 46 \\
Standard Deviation & 1.194560378 \\
\hline
\end{tabular}

Source: Field Survey, 2020

Taken all together the findings emphasize the link between socio-economic status and academic performance. The higher the socio-economic status of parents the higher the performance of students. The lower the socio-economic status of parents the lower the academic performance of students. This can be inferred from Becker's Household production theory which directly links household resources and investments to the educational attainment of children. Again, the theory further confirms that an educated mother is likely to have more bargaining power within the household and her preferences for educated children will play a larger role in the decision to send her children to school. The findings also revealed some exceptions where some students from low socio-economic background perform academically better than those from high socio-economic background due to high intelligent quotients.

\subsection{Testing hypothesis}

$\mathrm{H}_{\mathrm{o}}$ : Students from high socio-economic status families do not perform better academically than those from the medium and low socio-economic status families.

$\mathrm{H}_{\mathrm{a}}$ : There is no significant positive relationship between the Socio-economic Status of parents and students academic performance, $\mathrm{r}(103)=0.17, \mathrm{p}>0.05$ with a coefficient of -0.217 significant at 0.05 level (2-tailed). This indicates that students with high financial status of parents do not necessarily have high academic performance or are not necessary satisfy with their academic performance.

Table 12: Paired t test

\begin{tabular}{lllllll}
\hline Variable & Obs & Mean & Std. Err. & Std. Dev. & \multicolumn{2}{c}{ [95\% Conf. Interval] } \\
\hline SES | & 104 & 20.74038 & .667863 & 6.810892 & 19.41584 & 22.06493 \\
ACC | & 104 & 14.375 & .3164012 & 3.226671 & 13.74749 & 15.00251 \\
diff $\mid$ & 104 & 6.365385 & .7532674 & 7.681851 & 4.871456 & 7.859313 \\
\hline
\end{tabular}

Mean (diff) $=$ mean $($ SES - ACC)

$\mathrm{t}=8.4504$

Ho: mean $($ diff $)=0 \quad$ degrees of freedom $=103$

Ha: mean(diff) $<0 \quad$ Ha: mean(diff) $!=0 \quad$ Ha: mean(diff) $>0$

$\operatorname{Pr}(\mathrm{T}<\mathrm{t})=1.0000 \quad \operatorname{Pr}(|\mathrm{T}|>|\mathrm{t}|)=\mathbf{0 . 0 0 0 0} \quad \operatorname{Pr}(\mathrm{T}>\mathrm{t})=0.0000$

In order to find out whether there was a difference between parental involvement, Socio-economic status and academic performance, pair sample t-test was employed to achieve that end. T-test was used due to its ability of comparing the means of variables at different time periods.

Initially, a paired t-test was conducted to test whether there was a significant difference in parental involvement and Socio-economic status (SES) of parents. The results for the test are shown in the Table 11 $(\mathrm{df}=103, \mathrm{t}=8.4504, \mathrm{p}=0.000)$. Therefore, the null hypothesis was rejected since the $\mathrm{p}$-value is less than 0.05 . There is a significant difference in parental involvement and socio-economic status of parents. Hence, we conclude that parent's socio-economic status significantly affects parental involvement and students' academic performance. 
Table 13: Regression statistics

\begin{tabular}{|c|c|c|c|c|c|c|c|c|}
\hline \multicolumn{9}{|l|}{ Regression Statistics } \\
\hline Multiple R & 0.174888841 & & & & & & & \\
\hline R Square & 0.030586107 & & & & & & & \\
\hline Adjusted R Square & 0.021082049 & & & & & & & \\
\hline Standard Error & 3.192477715 & & & & & & & \\
\hline Observations & 104 & & & & & & & \\
\hline \multicolumn{9}{|l|}{ ANOVA } \\
\hline & $D f$ & SS & $M S$ & $F$ & Significance $F$ & & & \\
\hline Regression & 1 & 32.79977627 & 32.79978 & 3.218215578 & 0.075785818 & & & \\
\hline Residual & 102 & 1039.575224 & 10.19191 & & & & & \\
\hline \multirow[t]{2}{*}{ Total } & 103 & 1072.375 & & & & & & \\
\hline & Coefficients & Standard Error & tStat & $P$-value & Lower $95 \%$ & Upper $95 \%$ & Lower $95.0 \%$ & Upper $95.0 \%$ \\
\hline Intercept & 16.09342116 & 1.007759639 & 15.9695 & $1.6556 \mathrm{E}-29$ & 14.09453475 & 18.092308 & 14.094535 & 18.092308 \\
\hline SES & -0.082853871 & 0.046185456 & -1.793939 & 0.075785818 & -0.174462502 & 0.0087548 & -0.1744625 & 0.0087548 \\
\hline
\end{tabular}

The result was still further confirmed with regression and ANOVA (i.e. correlation). From the Table 13 we can conclude that, there is no significant positive relationship between the Socio-economic Status of parents and students academic performance, $\mathrm{r}(103)=0.17, \mathrm{p}>0.05$

\subsection{Discussion of the Socio-Economic Status of Parents and Academic Performance}

The objective of the study was to assess the relationship between the socio-economic status of parents and academic performance of Senior High School Students in the Mfantsiman Municipality. The socio-economic status of a family is capable of affecting the behaviour of the children and determines their aspiration. Families with high socio-economic status often have more success in preparing their children for school because they typically have access to wide range of options that provide their young children with high quality child-care, books, other educational materials and encourage their children in various learning activities at home. They also have easy access to information regarding their children's health, as well as social, emotional and cognitive development (Ojo \& Yilma, 2010). The results indicated that a number of household conditions which are socioeconomic status affect the academic performance of students. Out of the 104 respondents $58(56 \%)$ of them come from low socio-economic family background where there is low parental income, education with little or no occupation and the remaining 46 (44\%) coming from high socio-economic family background.

However, a cross tabulation analysis showed a negative relationship between financial status of parents and the academic performance of students. This is because the Pearson correlation exhibits a weak negative relationship with a coefficient of -0.217 significant at 0.05 level (2-tailed). This indicates that students with high financial status of parents do not necessarily have high academic performance or are satisfy with their academic performance. This backs the study conducted by Francis (2007) who opines that the lower income families may be aware of the importance of education in the society, but at the same time, they are also aware of their limited resources to measure up with such educational demands.

In contrast to this finding, it is believed that a family that can scarcely provide for the basic needs of the family which include food, shelter and clothing will hardly motivate the academic excellence of their children, instead they will pressurize their children to seek for job opportunities with the little education they acquired in order to support the family (Francis, 2007). The implication of the argument is that poor families are likely to give their children poor academic background because of lack of financial support. Similarly, Suleman, Aslam, Shakir, Akhtar, Hussain and Akhtar (2012), found that those children whose socio-economic status was strong showed better academic performance and those with poor socio-economic status showed poor and unsatisfactory academic performance.

The study also indicated that the fathers of the respondents have higher education background than the mothers and also a large portion of the mothers have education up to secondary school level or below. This scenario points to the skewness of educational attainment between males and females. It looks like males aspire to achieve more and higher educational laurels than their female counterparts. With regards to the parents' level of education, for the purposes of this research, as indicated in Table 5 from no formal education to education at the secondary level was considered as pre-tertiary education. Whilst education from the Diploma level to the post graduate level was considered as tertiary education. In view of this, $76(73.1 \%)$ percent of the mothers have low education as against $21(20.2 \%)$ who had high education. The finding on high education and high academic performance indicates that, socio-economic background with specific reference to parents' education has shown to have a positive influence on the academic performance of students (Jeynes, 2003; McMillan \& Western, 2000; Nyarko, 2011). Similarly, with regards to the fathers' occupation, only 33(31.7\%) were engaged in public sector works, whilst the rest engaged in private sector works and other sources of livelihoods. There were $4(3.8 \%)$ fathers who were unemployed. The situation of the mothers was worse as only $10(9.6 \%)$ engaged in public sector works while the rest engaged in private sector works and other jobs. There were $6(5.8 \%)$ mothers who were unemployed. There was connection between their level of education and the kind of work they engaged in. 
One of the basic determinants of household socio-economic status is the educational level of parents. In relation to Table 5, the education level of the fathers revealed $38(36 \%)$ had tertiary education, $63(61 \%)$ also had pretertiary education and $3(3 \%)$ had no formal education. The education level of the mothers indicated $21(20.2 \%)$ had tertiary education, 76(73.1\%) also had pre-tertiary education and 7(6.7\%) had no formal education. A closer look at the figures for the fathers and mothers reveal that the fathers have higher education than the mothers and also a large portion of the mothers have education up to secondary school and below. This scenario points to the skewness of educational attainment between males and females. This finding seems to support the household production theory as the fathers are in better position in terms of their educational level and occupation as compared to the mothers and are likely to take decision on allocation of resources as household heads (Becker, 1993). It seems males aspire to achieve more and higher educational laurels than their female counterparts. Besides, most families give opportunity to the male child in terms of higher education if family resources are inadequate.

The occupational status of the fathers showed that $43(41.3 \%)$ of them were formal sector workers (skilled), $57(54.9 \%)$ were informal sector workers whilst $4(3.8 \%)$ were unemployed. In the case of the mothers, only $18(17.3 \%)$ were in the formal sector. There were $80(76.9 \%)$ who worked in the informal sector whilst $6(5.8 \%)$ were unemployed. Parents are potential role models for their children. Taiwo (1993) submits that parents' educational background influences the academic achievement of students. This, according to him, is because the parents would be in a good position to be the second teachers to the child; and even guide and counsel the child to perform well in education and provide the necessary materials needed by the child. This was supported by Musgrave (2000) who said a child that comes from an educated home would like to follow the steps of his family and by this, work actively in his or her studies. Musgrave further indicated that parents who have more than a minimum level of education are expected to have favoured attitude to the child's education and to encourage and help him or her with school work. On the issue of respondents housing type or residential status, $35(33.7 \%)$ of them lived in compound house and $21(20.2 \%)$ of them live in detached houses and $19(18.3 \%)$ of them live in flat apartment. This explains the socio-economic background of the respondents. On the issue whether the money's received were enough, 64(61.5\%) of them said it is enough for them. This generally explained that the respondents were financially sound and were able to provide their needs. It was also confirmed by $60(57.7 \%)$ of the respondents that they do not support family income by selling or any other means.

The result of the hypothesis indicated that there is a parallel relationship between parental involvement and the socio-economic status of parents. It can therefore be concluded that parents' socio-economic status significantly affects their involvement in their children's education. That is there was a significant relationship. This finding affirms the household production theory which emphasises that a combination of time and resource inputs produce different types of commodities (Becker, 1993). In order to produce what Becker calls "quality children," parents need to spend time and devote resources to foster conducive environment that promotes formal education. This concurs with the findings of Hill et al. (2004) who suggested that the socio-economic status of parents not only influences the development of children at home but it also develops a competition among the students belonging to persons of different social and economic strata. Children whose parents had low socioeconomic status felt depressed as against students from higher socio-economic status (Eze, 2002). Laosa (2005) also states that the differences among the students exist due to the family backgrounds such as nutrition and health status, environment at home, income of parents, their educational level and experiences as well as means of recreation in the family are the main factors that affect the educational and social achievement of students. In the same vein, other researchers had posited that parental SES could affect school children in terms of their flexibility to adjustment to different school schedules (Guerin et al., 2001). Machebe's (2012) research concluded that parental socio-economic status could influence academic performance of their children at school. Machebe (2012) has made the conclusion that the socio-economic status of parents influences the academic performance of students to a certain degree in the schools. Likewise, Escarce (2003) who maintains that most underachievers come from the lower socio-economic levels of the home-environment and that the psychosocial encouragement contributes very little towards improving the intellect.

Similarly, Eze (2002), and Hill et al. (2004) had asserted that status of parents does not only affect the academic performance of students but also make it impossible for children from low socio-economic background to compete well with their counterpart from high socio-economic background under the same academic environment. They had also posited further that illiterate and semi-illiterate parent with feeling of inadequacy may not be able to help their children out of different academic problems. Thus, the academic performance of such children is greatly hindered.

\section{CONCLUSIONS AND RECOMMENDATIONS}

Household conditions such as parents' socio-economic status in terms of occupation, educational background, income level, and parents' involvement in child's education are important factors that determine the academic 
performance of students in the Mfantsiman Municipality. The educational and income statuses have a positive relationship with the academic performance of students. This is because parents themselves having been to school realised the importance of education. They stand a better position to support their children for better academic performance. This implies that low socio-economic status may result in poor academic performance of children. However, due to natural endowments in children such as high intelligence as well as the motivation to break the vicious cycle of poverty, some children though from low SES households perform better academically than those from high SES households. In the same vein, some students from high SES performed poorly academically. It can therefore be concluded that socio-economic status alone does not account for high students' academic performance in all children but natural endowments in children also contribute to high students' performance.

It is recommended that parents should be encouraged to get themselves engaged in economic activities to improve their economic power and educate themselves to be able to meet the educational needs of the children which will result in high academic performance of students.

Parents should play a leading role in their children's education by encouraging their wards to discuss issues related to their academic work with them. They should provide their children's educational needs and appropriate support in school work.

NGOs, stakeholders and other well-to-do individuals must consider providing extra support for children from disadvantaged socio-economic backgrounds. For instance, supply of school uniforms and learning materials to needy children.

The government should implement School Feeding Programme in all Senior High Schools in the District. As a result of the low socio-economic status of majority of parents as indicated by the study, some of the students do not eat well at home before going to school or not given enough pocket money to school. Some students do not eat at home before going to school. This has serious implication on their health and consequently their physical, mental and psychological development. The effective implementation of School Feeding Programme in all schools in the Municipality will help children to maintain a healthy physical and mental development and thereby increase their attention and performance in school.

Members of the communities should be trained by NGO's and Corporate bodies and the government through the Municipal Assembly, to acquire employable skills. The government through the Municipal Assembly and individuals should create jobs and this will improve the socio-economic status of parents and will consequently enhance the academic performance of students in the study area since the improvement in income of parents to a large extent result in improved students' performance.

\section{REFERENCES}

Adebule, S. O. (2004). Gender differences on a locally standardised anxiety rating scale in Mathematics for Nigeria secondary school. Nigeria Journal of Counseling and Applied Psychology, 1(1), 22-29.

Adell, M. A. (2002) Strategies for improving academic performance in adolescents. Piramide.

Adesehinwa, O. A. (2013). Effects of family type (monogamy or polygamy) on students' academic achievement in Nigeria. Intl J. of Psychology and Counselling, 5(7), 153-156.

Adesehinwa, O. A., \& Aremu, A. O. (2010). The relationship among predictors of child, family, school, society and the government and academic achievement of senior secondary school students in Ibadan, Nigeria. Journal of Social and Behavioural Sciences, 5, 842-849.

Adewale, A. M. (2002). Implication of parasitic infections on school performance among school-age children, Ilorin Journal of Science Education, 2, 78-81.

Agus, A. \& Makhbul, M. G. (2002). An empirical study on academic achievement of business students in pursing higher education: An emphasis on the influence of family backgrounds. Paper presented at international conference on the challenges of learning and teaching in a Brave New World: Issues and opportunities in Borderless education. Hatyai Thailand.

Al-Samarrai, S., \& Peasgood, T. (1998). Educational attainment and household characteristics in Tanzania. Economics of Education Review, 17(4), 395-417.

Anderson, B., Benjamin, H., \& Fuss, M. A. (1994). The determinants of success in university introductory economics courses. Journal of Economic Education, 25, 99-119.

Barnard, W. M. (2004). Parent involvement in elementary school and educational attainment. Children and Youth Services Reviews, 26, 39-62.

Barrera-Osorio, F., Bertrand, M., Linden, L. L., \& Perez-Calle, F. (2008). Conditional cash transfers in education design features, peer and sibling effects evidence from a randomized experiment in Colombia (No. w13890). National Bureau of Economic Research.

Battle, J., \& Lewis, M. (2002). The increasing significance of class: The relative effects of race and socioeconomic status on academic achievement. Journal of Poverty, 6(2), 25-35.

Becker, G. S. (1993). Human capital: a theoretical and empirical analysis, with special reference to education. 
University of Chicago Press.

Bergeson, T. (2006). Race, poverty, and academic achievement. Retrieved from http://www.doh.wa.gov/SBOH/ESS/documents/Race \& Poverty.pdf.

Bermejo, R. (2014). Sustainable development in the Brundtland report and its distortion. doi=10.1007/978-94017-8981-3 5

Bjorkman, M. (2005). Income shocks and gender gaps in education: Evidence from Uganda for job market paper. Journal of Development Economics, 105, 237-253.

Blanden, J., \& Gregg, P. (2004). Family income and educational attainment: A review of approaches and evidence for Britain. Centre for the Economics of Education.

Bower, H. A., \& Griffin, D. (2011). Can the Epstein model of parental involvement work in a high-minority, high-poverty elementary school? A case study. Professional School Counseling, 15(2), 77-87.

Chakraborty, B. (2018). Education as an instrument of social change and enhancing teaching-learning process with the help of technological development. Retrieved from https://http/ICTE18_SaikatChakraborty.pdf

Checchi, D. (2000). An inverted U-shape relationship between educational achievement and income inequality. University of Milan - Italy.

Colclough, C., Rose, P., \& Tembon, M. (2000). Gender inequalities in primary schooling: the roles of poverty and adverse cultural practices. International Journal of Educational Development, 20, 5-27.

Deng. T. T., \& Nelson, J. D. (2010). Questionnaire for students: Survey from Beijing Southern axis line 1. World Academy of Science, Engineering and Technology, 66, 1196-1206.

Diaz, A. L. (2003). Personal, family academic factors affecting low achievement in secondary school. Journal of Research in Educational Psychology and Psychopedagogy, 1(1), 43-66.

Duke, N. K. (2000). For the rich it's richer. American Educational Research Journal, 17, 441-478.

Eamon, M. K. (2005). Social-demographic, school, neighbourhood, and parenting influence on academic achievement of Latino young adolescents. Journal of Youth and Adolescence, 34(2), 163-175.

Elliot, A. (2007). A conceptual history of the achievement goal construct. In A. Elliot \& C. Dweck (Eds.), Handbook of competence and motivation (pp.52-72). Guilford Press.

Emeke, E. A. (1999). Relationship between personal problems and study habits. J. Appl. Psycho., 3, 113 - 129

England, M. M., Luckner, A. E., Whaley, G. J. L., \& Egeland, B. (2004). Children's achievement in early elementary school: Longitudinal effects of parental involvement, expectations and quality of assistance. Journal of Educational Psychology, 96, 723-730.

Ermisch, J., \& Francesconi, M. (2001). Family matters: Impacts of family background on educational attainments. Economica, 68, 137-56.

Escarce, J. J. (2003). Socio-economic status and the fates of adolescents. Health Serv. Res., 38, 1229-1234.

Eze, O. M. (2002). The effects of parental economic status and pupil sex on school achievement in English Language. Journal of Vocational and Technical Education, 3(3), 27-39.

Fairlie, R. W. (2005). The effects of home computers on school enrolment. Economics of Education Review, 24(5), 533-547.

Fan, W., \& Williams. C. M. (2010). The effects of parental involvement on students' academic self-efficacy, engagement and intrinsic motivation. Educational Psychology, 30(1), 53-74.

Farooq, M. S., Chaudhry, A.H., Shafiq, M., \& Berhanu, G. (2011). Factors affecting students' quality of academic performance: a case of secondary school level. Journal of Quality and Technology Management, $7(2), 01-14$

Filmer, D., \& Pritchett L. H. (2001). Estimating wealth effect without expenditure data or tears. An application to educational enrolment in States of India. Demography, 38, 115-132.

Filmer, D., \& Scott, K. (2008). Assessing assets indices. World Bank, Policy Research Working Paper. No. 4605.

Francis, H. (2007). The Global Superorganism: an evolutionary-cybernetic model of the emerging network society. Social Evolution and History, 6(1).

Georgiou, S. N. (2007). Parental involvement: Beyond demographics. International Journal of Parents in Education, 1, 59-62.

Ghana Statistical Service (GSS) (2010). Ghana living standard survey. GSS.

Ghana Statistical Service (GSS). (2012). 2010 Population and housing census summary report of final results. GSS.

Glick, P., \& Sahn, D. E. (2009). Cognitive skills among children in Senegal: Disentangling the roles of schooling and family background. Economics of Education Review, 28(2), 178-188.

Goodlad, J. I. (1984). A place called School: Prospects for future. McGraw Hills.

Grim, J., Medina, M. A., Cosby, G., \& Brodnax, R. (2020). The power of community school councils in urban schools. Peabody Journal of Education, 95(1), 73-89.

Guerin, N., Reinberg, A., Testu, F., Boulenguiez, S., Mechkouri, M., \& Touitou, Y. (2001). Role of School schedule, age and parental socio-economic status on sleep duration and sleepiness of Parisian children. 
Chronobio Int.,18(6), 1005-1017.

Haddad, L. J., Hoddinott, J., \& Harold Alderman. (1994). Intrahousehold resource allocation: An overview. World Bank, Policy Research Department.

Heyneman, S. P. (2005). Student background and students' achievement: What is the question? American Journal of Education, 112, 1-9.

Hijazi, S. T., \& Naqvi, S. M. (2006). Factors affecting students' performance: A case of private colleges. Bangladesh E-Journal of Sociology, 3 (1), 65-99.

Hill, N. E., \& Taylor, L. C. (2004) Parental school involvement and children's academic achievement: pragmatics and issues: Association of psychological science. American Psychological Association, 13(4), 161-164

Hill, N. E., Castelino, O. R., Lansford, J. E., Nowlin, E., Dodge, P., Bates, K. A., \& Pettit, G. S. (2004). Parents academic involvement as related to school behaviour, achievement and aspiration: Demographic Variations Across Adolescence Child development 75(5), 1491-1509.

Hochschild, A. R. (2003). The commodity frontier. The commercialisation of intimate life: Notes from home and work. University of California Press.

Hossler, D., Schmit, J., \& Vesper, N. (1999). Going to college: How social, economic and educational factors influence the decisions students make. John Hopkins University Press.

Jekayinfa, A. A., \& Oke, C. S. (2003). Sociology of education. Tobistic Printing and Publishing Ventures.

Jeynes, W. H. (2003). A meta-analysis: The effects of parental involvement on minority children's academic achievement. Education and Urban Society, 35, 202-218.

Johnson, V. E. (2003). Grade inflation: A crisis in college education. Springer-Verlag.

Kabeer, N. (1991). Cultural dopes or rational fools? Women and labour supply in the Bangladesh garment industry. European Journal of Development Research, 3(1), 133-160.

Kothari, C. R. (2004). Research and methodology: methods and techniques. Journal of School Psychology, 38(6), 501-523.

Laosa, L. M. (2005). Effects of preschool on educational achievement. NEER.

Lee, J. Y. (2013). Private tutoring and its impact on students' academic achievement, formal schooling, and educational inequality in Korea. Columbia University: Unpublished PhD thesis.

Lincove, J. A. (2009). Determinants of schooling for boys and girls in Nigeria under a policy of free primary education. Economics of Education Review, 28(4), 474-484.

Local Government (2016). Local Governance, Act of 2016, Act 936. Retrieved from https://lgs.gov.gh/index.phd/local.governance -act-of-2016-act-936.

Luckner, J. L., \& Velaski, A. (2004). Healthy families of children who are deaf. American Annuals of the Deaf, 149 (4): 324-35.

Machebe, C.H (2012). Influence of parental socio-economic status on students' academic achievement in Secondary Schools in Ezeagu L. G. A. of Enugu State. (An Unpublished thesis in the department of Educational Foundations University of Nigeria Nsukka)

McMillan, J., \& Western, J. (2000). Measurement of social-economic status of Australian higher education students. Higher Education, 39(2), 25-53.

Meece, J. L. (2002). Child and adolescent development for educators (2nd ed.). McGraw-Hill Companies, Inc.

Morakinyo, O., \& Fatoye, F. O. (2003). Psychopathology among senior secondary school students in Ilesa, South Western Nigeria. Niger Postgrad Med Journal, 10(3), 182-187.

Moshi, K. I. (2015). Comparative study on adaptation strategies by rural households in response to food security in Tanzania: A case study of Burunge Wildlife Management Area. Masters Thesis. University of Copenhagen

Mugenda, P., \& Mugenda, M. (2003). Research methods: Qualitative and quantitative methods. Laba Graphics Service

Muhammed, F. J., \& Muhammed A. K. (2010). Impact of parental socio-economic status on students' educational achievements at secondary schools of District Malir. Middle-East Journal of Scientific Research 6(6), 678-687.

Muola, J. M. (2010). A study of relationship between academic achievement, motivation and home environment among standard eight pupils. Egerton University of Kenya.

Musgrave, C. B. (2000). Environmental factors affecting attitude towards Science and Mathematics. Journal of Educational Psychology, 91(1), 382-394.

Nyarko, K. (2011). Parental school involvement: The case of Ghana. Journal of Emerging Trends in Education Research and Policy Studies, 2(5), 378-381.

Obeta, A. O. (2014). Home environmental factors affecting students' academic performance in Abia State, Nigeria. Michael Okpara University of Agriculture Umudike, Abia State Nigeria.

Ogbemudia, M. I., \& Aiasa, M. V. (2013). Influence of home environment on the academic performance of 
primary five pupils in English Language. Research journal of Education and Review, 1(5), 120-125.

Ojeka, S. (2011). Tax policy and growth of SMEs: Implications for the Nigerian economy, Research Journal of Finance and Accounting. 2(2), $2222-2847$

Ojo, B. J. S., \& Yilma, T. (2010). Comparative study of the influence of the home background on students' achievement in Mathematics in Bensihangul Gumuz Regional State of Ethiopia. African Research Review, $2(1), 94-108$.

Omoegun, M. (2007). Effect of parental socio-economic status on parental care and social adjustment in the UBE programme in Lagos State: Implication for counseling. International Journal of Educational Research, $3(2), 81-87$.

Oni, A. A. (2007). Socio-economic status as predictor of deviant behaviors among Nigeria secondary school students. International Journal of Educational Research. 3(2), 225-236.

Osuala, E. C. (2005). Introduction to research methodology. African First Publishers.

Ramey, C. T., \& Ramey, S. L. (1994). The transition to school: Why the first few years matter for a lifetime. Phi Delta Kappan, 76(30), 48-66.

Reynolds, J. R., \& Pemberton, J. (2001). Rising college expectations among youth in the United States: A comparison of the 1979 and 1997 NLSY. Journal of Human Resources, 36(4), 703-726.

Robson, C. (2002). Real world research: A resource for social scientists and practitioner-researchers. Blackwell.

Rothestein, R. (2004). Class and schools using social economic and educational reforms to close the white and black achievement gap. Economic Policy Institute.

Rowan, B., Cohen, D. K., \& Raudenbush, S. W. (2004). Improving the educational outcomes of students in poverty through multidisciplinary research and development. Retrieved from http://www.isr.umich.edu/carss/about/Prospectus.pdf.

Schmitt J. J., \& Wadsworth, (2006). Home computer use and academic performance of nine-year-olds. Oxford Review of Education, 38(5), 617-634.

Schulz, W. (2005). Measuring the socio-economic background of students and its effect on achievement in PISA 2000 and PISA 2003. American Educational Research Association.

Sen, A. (1990). Gender and cooperative conflict, in persistent inequalities. Oxford University Press.

Sentamu, N. P. (2003). Schools influence of learning: A case of upper primary schools in Kampala \& Wakiso Districts. Uganda Educ. J., 4, 25-41.

Smith, L. Fagan, J. F., \& Ulvund, S. E. (2002). The relation of cognition memory in infancy and parental socioeconomic status to later intellectual competence. Intelligence, 30 (2), 247-259.

Suleman, Q., Aslam, H. D., Shakir, M., Akhtar, S., Hussain, I., \& Akhtar, Z. (2012). Effects of family structure on the academic performance of students at elementary level. Journal of Sociological Research, 3(2), 34-41.

Tahir, S., \& Naqvi, S. R. (2006). Factors affecting students' performance. Bangladesh Journal of Sociology, 3(1), 12-19.

Taiwo, H. G. (1993). Family environment and educational attainment of some school children in Western Nigeria. Journal of the Science Teachers Association of Nigeria, 46(2), 107-11.

Tinto, V. (1993). Limits of theory and practice in student attrition. Journal of Higher Education, 53, 687-700.

UNESCO (2013). Framework for action on values of education in early childhood. Early Education Unit, UNESCO.

UNESCO (2015). Family background and literacy performance. Retrieved from https://www.oecd.org/dataoecd3369905591.

UNESCO (2018). Global education report. Retrieved from https://unesdoc.unesco.org-ark.

United Nations (2010). Handbook on population and housing census. UN.

Welman, C., Kruger F., Mitchell, \& B. (2005). Research methodology. Oxford University Press.

Yin, R. K. (1994). Case study research: Design and methods. Sage.

Yusuf, N., \& Kainuwa, A. (2013). Influence of socio-economic and educational background of parents on their children's education in Nigeria. International Journal of Scientific and Research Publications, 3(10), 1-8.

Zhao, M., \& Glewwe, P. (2010). What determines basic school attainment in developing countries? Evidence from rural China. Economics of Education Review, 29(3), 451-46.

Zikmund, W. G. (1994). Business research methods (4th ed). Dryden Press. 